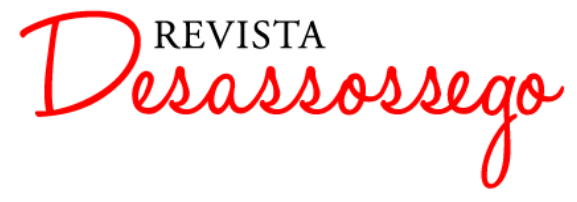

DESASSOSSEGO 14 | DEZ/2015 | ISSN 2175-3180

DOI: http://dx.doi.org/10.11606/issn.2175-3180.v7i14p188-190

\title{
3 POEMAS DE LUIS MAFFEI
}

Luis Maffei ${ }^{1}$

\section{MIND THE GAP}

Quando ela disse mind the gap eu pensava em fronteira e

entre-lugar um pouco por causa do Juan Carlos Mestre

lido por mim em rica segunda mão

Ele leu o Dante do mezzo del camin ali por seus

38 círculos 38 anos

(quem me disse foi a tese do Ordóñez)

Isso também por causa de um poema

"Fronteira"

do José Tolentino Mendonça e de outro seu

quase tenção sobre o fim da arte tida com alguém que teve 25 anos

hipótese de metade do caminho de limite de

nem lá nem cá aqui e ali ao mesmo tempo

São os poetas que me ensinam a observar

atentamente o espaço entre o trem e a plataforma

\section{O ELASTANO}

Há uma mulher no intervalo entre duas séries

Até onde eu vi a pegada é pronada e ela fez

cara de quem não sente mais nem

menos que um esforço seu possível

moto não sem ruga sem gemido

sem

justo no retângulo em que a morte é mais discreta que uma máscara

desespero

Quando é intervalo olha ela ${ }^{1}$ Poeta, ensaísta e professor de Literatura Portuguesa da Universidade Federal Fluminense. Publicou
A (2006), Telefunken (2008), 38 círculos (2010), Pulsatilla (2011), Signos de Camões (2013) e 40 (2014). 
no acostamento do antebraço esquerdo que

sustenta seu queixo parte da maçã

suor no pouco pelo que não vejo

nada

¿Que vê? ¿Que ver quando no tempo

há pronação para um diante que é outra

série de remadas

uma duas três quatro cinco seis sete oito no-

va pausa e um outro olhar que se prolonga ao

infinito de uma sala com espelhos e

tristeza?

¿e há tristeza?

Há uma mulher no intervalo entre as estrias do meu

sangue e o abandono

um olho que não rema enquanto há vida e ela não pensa

penso

a pronação como metáfora da morte nem a

remada como vida que se leva

ela é os olhos vistos que se vão onde não hei nem o

aparelho cor de prata e de borracha

ela é seu rosto sustentado no antebraço

possível moto

lícito infinito em que não estou nem

está a sala o espelho a gota

o elastano

\section{TREM FANTASMA}

Ficaremos aqui ainda um longo tempo

antes de a paisagem se mover

¿E se quem move as coisas é este trem

fantasma movido à propulsão das paisagens

lenha vapor discurso reza braba? 


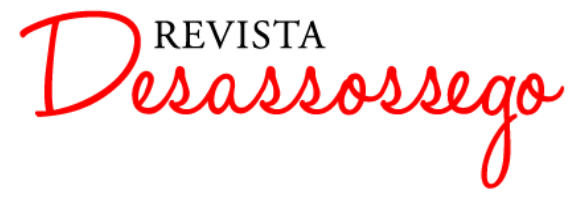

DESASSOSSEGO 14 | DEZ/2015 | ISSN 2175-3180

DOI: http://dx.doi.org/10.11606/issn.2175-3180.v7i14p188-190

Ficaremos aqui ficaremos se

houvesse simpatia um longo tempo

antes de haveremos de azeitar-se o chamamento do

caminho o cumprimento de verdade

Ficaremos ficaremos é o caminho a

torre à vista a terra

não

porém

se a esquina fosse o último prodígio

(¿onde eu te encontro se o banquinho

espatifou-se se houve dano

dolo espia na cabana onde eu te

encontro onde? Acho que escutaram

o telefone o nosso o grampo é de um fantasma

sem transporte)

de inventor sem companhia a adquirir

seu préstimo

hematoma

Ainda um longo tempo à espera da

revista da tragédia do recurso que

fome ou ânsia de comer depressa o

prato é a fome correr contra o tempo com

amortecimento de última geração em

nossos pés de atleta

¿Ficaremos onde? Ficaremos onde o

tempo trama a sua página

(¿paisagem?)

Fica aqui que o tempo é pouco cada

minuto cont

r

a

e paisagens são espécies preguiçosas 